\title{
初中语文教学中诚信教育的实现对策
}

毕雪莲

山东牡丹区二十一中学

DOI:10.32629/jief.v2i7.1913

[摘 要] 诚信是中华民族的传统美德, 诚信教育是培养学生诚信的好习惯、促进学生身心健康的重要方式, 对学生的终身发展具有重大意义。 初中语文教学是初中教育的重要基础课程之一，其中诚信教育的顺利开展有利于学生的学习和自身素质的提升。

[关键词] 初中语文教学; 诚信教育; 现状; 实现对策

中图分类号: G633.3 文献标识码: A

诚信作为中华民族的传统美德，是立足于社会的重要支撑。初中阶 段, 学生的个人世界观尚未成型, 对世界的认知处于初步阶段, 性格及 处世为人的准则尚在形成阶段, 容易被外界事物所影响, 个人素质水平 急需提高。良好的世界观、价值观和人生观的形成, 有利于学生的全面 发展。随着社会的不断发展, 社会中的诚信问题日益严重, 经济的快速 发展、物质生活的优越, 导致社会出现诸多乱象。初中生如果得不到良 好的诚信教育, 将直接影响学生的身心健康, 对学生的终身发展造成严 重影响。初中语文教学是对学生进行素质教育的重要教学阶段, 是对学 生进行诚信教育的重要途径。如何实现初中语文教学中的诚信教育是当 下初中教育的重要发展方向。

\section{1 初中语文教学中诚信教育的现状}

目前来看, 初中语文教学中的诚信教育仍面临着诸多问题, 其中不 少问题值得反思:

其一, 诚信之教, 必作于易, 不可仅依赖于道德与法治课程。初中 阶段开设《道德与法治》课程, 其主要目的是对学生进行品德培养与法治 教育, 而诚信作为社会核心价值观中极为重要的一部分, 一直是教学的重 点内容。然而, 这也造成了一个事实: 其它教师包括语文教师将诚信教学 视为道德与法治课程的教学责任, 而忽略了在各学科常规教学中有效渗 透, 致使诚信理念在综合教育过程中日渐式微。这实际上是一种观念上 的错误, 教书育人是教师最为基本的职责, 而诚实守信作为中华民族的传 统美德, 对促进学生的身心健康成长起着极为重要的作用, 不可等闲视 之。

其二, 诚信之育, 必作于细, 不可放任学生不拘小节。在实际教学 过程中存在这样一种现象, 即教师认为初中生年龄较小, 很多道理尚且不 明白亦情有可原。进而, 面对学生的失信行为时, 没有进行适时的诚信教 育, 没有意识到中学生所处的年龄段正是人格形成的关键时期。外界事 物对学生个人价值观和世界观的形成具有重大影响, 而这种放任很容易 让学生产生侥幸心理和错误认知, 如养成不良习惯, 星星之火亦可燎原, 若为时已晚, 岂不令人痛惜。因此, 教师应注重细节, 抓住教育契机, 给学生以最适时而正确的指导、帮助。

当今社会, 伴随科技的快速发展, 学生所接触的信息良莠不齐, 然 而他们明辨是非的能力较弱。因此, 初中语文教学更要明确让学生树立 诚信意识, 真诚待人、信守承诺。运用诚信智慧, 促进学生的身心健康 成长。

1.1 诚信教育在初中语文教学中目标不够明确

诚信教育在初中语文教学中存在已久, 但随着非诚信问题的发生率 越来越多, 目前教学中诚信教育水平有待提高。当前的诚信教育要明确 教学目标, 明确教学方向。目前, 教学中的诚信教育缺乏明确的教学目 标, 教学方向上存在偏差, 不利于诚信教育的有效实施。在教学过程中, 教师一味的追求教学进度, 忽视了学生的学习感受。应当将学生的需求 与诚信教育的目的相结合, 使诚信教育渗透到学生的生活中, 促进诚信 教育的发展, 提升学生的素质水平。

1.2 消极的外界影响
随着科技的不断发展, 网络在社会中的运用愈发广泛, 基本达到全 民普及的程度。但网络信息的快速传播, 导致学生接触网络上的不良信 息可能性增加, 直接影响学生正确价值观的形成。学生在教学过程中, 会利用网络查取资料, 容易受到不良信息的影响, 损害学生的诚信教育。 此外, 教师也应当规避学生受到社会的不良影响, 避免学生顾及一时的 利益忽视诚信的重要性。

\section{2 初中语文教学中诚信教育的实现对策}

目前诚信教育中存在的诸多问题需要初中语文教学进行深化改革, 明确诚信教育的教学目标, 革新教育理念, 实现初中语文教学的诚信教 育。

\section{1 革新教学理念}

初中语文教学中的诚信教育, 以培养学生的诚信精神为目的, 将诚 信品质与语文教学内容相结合, 以学生为教学主体, 关注学生的教学感 受, 促进诚信教育的发展。教师应当重视学生正确诚信观的形成, 初中 阶段的学生容易受到外界事物的影响, 教师可以通过树立自身形象, 以 自身为榜样教导学生, 使学生直观的感受诚信的重要性, 从而有效培养 学生的诚信意识。

2.2 与基础教育相结合

在日常教学中, 教师需要将诚信教育与教学内容相结合。在教材中 结合诚信知识、诚信理念, 掌握基本知识, 以此为基础, 实现诚信教育。 同时, 配套专业教材, 进行适当的诚信教育培训, 增加教学的多样性, 使教师得到专业指导, 提升诚信教育的教学质量, 引导学生对诚信教育 形成正确的认知, 充分认识到诚信教育对终身发展的重要性。

\section{3 完善教学内容}

在初中语文教学中, 教学以教材为基础, 而诚信教育的内容相对较 少。因此, 教师应当完善诚信教育的教学内容, 对教材进行深化解读, 将其中的诚信品质展现出来。同时, 在教学过程中, 教师需要引导学生 将诚信教育的理论知识与实际情况相结合, 丰富教学内容, 使学生切实 体会诚信教育, 激发学生的学习兴趣。此外, 教师可以引导学生拓宽课 外诚信知识, 带领学生研读课外读物, 收集诚信案例、成语、寓言, 增 强学生对诚信的理解。

\section{3 总结}

随着社会的快速发展, 信息传递速度加快, 逐渐实现了信息的共享, 但也使得学生容易受到网络信息的不良影响, 对学生的诚信教育及素质 培养带来严重后果。初中阶段, 应当充分重视学生的诚信教育, 深化改 革诚信教育方式, 促使学生身心健康发展。

\section{[参考文献]}

[1]方丽云.初中语文教学中诚信教育的实现策略研究 [J].考试周 刊,2020,(4):36-37.

[2]杨晓哲. 初中语文教学中融入德育教育的途径 [J]. 考试周 刊,2018,(77):74.

[3]罗博.浅析初中语文诚信教育[J].活力,2019,(8):125. 